\title{
EFFECT OF NITROGEN ON THE STARCH FORMATION AND YIELD OF HIGH-DENSITY SORGHUM [SORGHUM BICOLOR (L.) MOENCH] IN NORTHERN CHINA
}

\author{
YANG, G. D. ${ }^{1,2}-$ HU, Z. Y. ${ }^{2}-$ HUANG, R. D. ${ }^{1}-$ HAO, Z. Y. ${ }^{2}-$ LI, J. H. ${ }^{2}-$ WANG, Q. ${ }^{3}-$ \\ MENG, X. X. ${ }^{3}-$ ZHOU, Y. F. ${ }^{1^{*}}$ \\ ${ }^{1}$ College of Agronomy, Shenyang Agricultural University, No. 120 Dongling Road, Shenyang \\ 110866 Liaoning, China \\ ${ }^{2}$ Keshan Branch of Heilongjiang Academy of Agricultural Sciences, 161005 Heilongjiang, \\ China \\ ${ }^{3}$ Crop Resources Institute of Heilongjiang Academy of Agricultural Sciences, 150086 \\ Heilongjiang, China \\ *Corresponding author \\ e-mail:zhouyufei2002@aliyun.com; zhouyufei@syau.edu.cn
}

(Received 29 $9^{\text {th }}$ Jan 2020; accepted $9^{\text {th }}$ Jul 2020)

\begin{abstract}
Sorghum [Sorghum bicolor (L.) Moench] is an important plant in an arid and semi-arid part of China. The application of nitrogen is a basic element necessary for sorghum growth. In this study, Keza15 and Suiza7 were used as experimental materials in northern china to study the relationship among nitrogen and the accumulation of starch and the yield. The results showed that the total starch accumulation of the low-N-sensitive variety had a larger change range than the low-N-tolerant varieties. From 7 to 21 days after powder dispersal was a rapid growth period of starch accumulation and played an important role in the starch synthesis of grains. The yield of the two different genotypes of sorghum increased first and then decreased with a higher rate of nitrogen application. The best nitrogen application amount was $200 \mathrm{~kg} \mathrm{~N} \mathrm{ha}^{-1}(\mathrm{~N} 200)$. The application of nitrogen was beneficial for the increase of Soluble starch synthase (SSS), Starch branching enzyme (SBE), Bound starch synthetase (GBSS), Adenosine diphosphate glucose pyrophosphorylase (AGP), Uridine diphosphate glucose pyropitase activities (UGP), but the excessive nitrogen application led to a decrease. The effect of nitrogen on the activity of starch related enzymes for the low- $\mathrm{N}$-sensitive sorghum was stronger than that for the low-N-tolerant sorghum. Keywords: sorghum, nitrogen application rates, starch synthesis, high density, key enzyme
\end{abstract}

\section{Introduction}

Sorghum [Sorghum bicolor (L.) Moench] is the main food and economic crop in arid and semi-arid areas and is widely used in feed, brewing, energy, food processing and other fields (Wang et al., 2015). In the past few decades, the increase of sorghum yield were mainly attributed to the production increase in barren field (or low yield field) (Ciampitti et al., 2016). Nitrogen fertilizer is an important nutrient element in sorghum growth, reasonable application of nitrogen and sufficient nitrogen supply could alleviate the individual competition for nitrogen fertilizer, and improve the yield effectively (Mahama et al., 2014; Van weelden et al., 2016; Komla et al., 2019). However, excessive application of nitrogen fertilizer will lead to late maturity, lower harvest index, and lower nitrogen utilization efficiency (Liang et al., 2017). On the other hand, the excessive application of $\mathrm{N}$ results in decreased crop yields and environmental pollution (Jin et al., 2012). How to limit the negative impact of agricultural practices 
and increase crop production sustainability has been one of the key agricultural challenges (Ronga et al., 2019; Tilman et al., 2011).

Starch is the main component of sorghum grain, which consists of amylose and amylopectin. The proportion and quantity of amylose and amylopectin in the grain affect the quality of starch. Amylopectin content has an important impact on the palatability of sorghum and brewing quality (Ge et al., 2016). The application of nitrogen fertilizer is an effective means to improve the yield of sorghum, which can improve the accumulation of photosynthetic products, promote the formation of grain yield, which play an important role increasing production (Wang et al., 2015; Zhou et al., 2016). Nitrogen is involved in the synthesis of enzymes and their cofactors that regulate plant biochemical reactions. It is an important structural material in plants and one of the most critical elements in the process of carbon and nitrogen metabolism. Starch synthesis is a biochemical reaction process involving the coordination of many enzymes. The catalytic enzymes mainly include ADPG pyrophosphorylase, starch synthetase, starch branching enzyme, debranching enzyme and starch phosphorylase (Yan, et al., 2009).

In recent years, with the improvement of sorghum breeding level, sorghum has undergone a transformation from traditional tall-stalk and rare-planting to dwarf and high-density planting (Li et al., 2018). At present, the suitable planting density of dwarf sorghum in Heilongjiang Province is 300000 plants per hectare (Shen et al., 2013; Yang et al., 2015), which is the area with the largest sorghum planting density in China. The effect of nitrogen fertilizer on starch accumulation of sorghum grain has been reported, but the design of cultivation conditions is different. Previous studies focused on the effect of nitrogen on the yield and quality of sorghum, and high stem and sparse planting were mainly used for research background (Yu et al., 2008; Yi et al., 2014; Ge et al., 2016). There are few reports about the effect of high-density planting of sorghum starch in northern china. In this study, Keza15 and Suiza7 were used as experimental materials to study the relationship between nitrogen and starch yield, starch-related enzyme activity, and yield of different genotypes of sorghum under natural conditions. The physiological response and different mechanisms of starch accumulation and related enzyme activity of different genotypes of sorghum were clarified. It is of great significance to understand the nitrogen effect and metabolic mechanism of starch accumulation of high-density sorghum planted in an alpine area and to lay a foundation for the formulation of high-yield and high-quality cultivation technology.

\section{Materials and methods}

\section{Trials materials}

Keza15 and Suiza7 were obtained from the Keshan branch of the Heilongjiang Academy of Agricultural Sciences (Qiqihar City, Heilongjiang Province, China). Note: Keza15: the low-N-tolerant variety; Suiza7: the low-N-sensitive variety (Yang, et al., 2019) (Fig. 1).

\section{Trials conditions}

Agronomic trials were performed in an open field at Keshan $\left(48^{\circ} 03^{\prime} 47^{\prime \prime} \mathrm{N}\right.$, $125^{\circ} 87^{\prime} 57^{\prime \prime} \mathrm{E}$ ) (Qiqihar City, Heilongjiang Province, China) in 2017. The former crop was kidney bean, and the experimental soil was a chernozem. The 0-20 cm deep soil in 
the plow layer had the following characteristics: organic matter $3.2 \times 10^{4} \mathrm{mg} \cdot \mathrm{kg}^{-1}, \mathrm{pH}$ 6.12 , alkali hydrolyzed nitrogen $173 \mathrm{mg} \cdot \mathrm{kg}^{-1}$, available phosphorus $28.8 \mathrm{mg} \cdot \mathrm{kg}^{-1}$ and available potassium $307.2 \mathrm{mg} \cdot \mathrm{kg}^{-1}$.
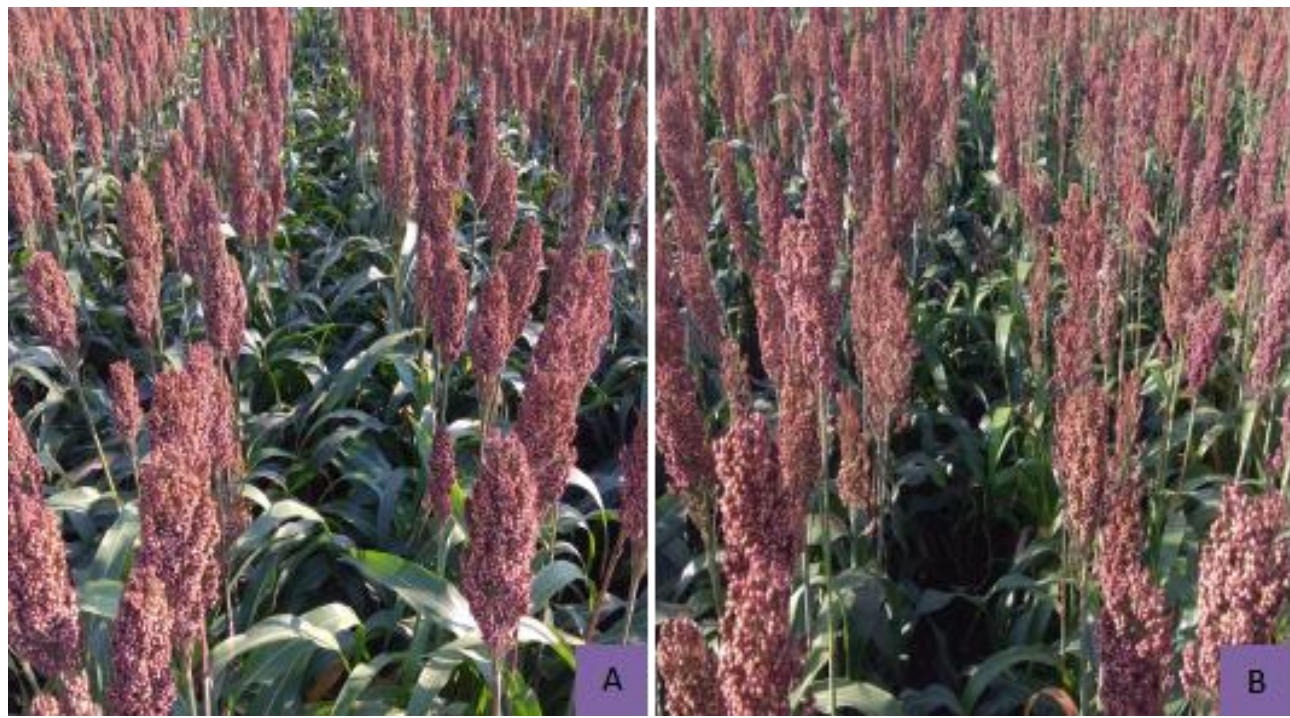

Figure 1. The field growth photos of two sorghum varieties during waxing stage under N100 treatment. (A) Keza15. (B) Suiza7

Four nitrogen treatments were set up, and urea was used as the nitrogen source: $0 \mathrm{~kg}$ (N0), $100 \mathrm{~kg}(\mathrm{~N} 100), 200 \mathrm{~kg}(\mathrm{~N} 200)$ and $300 \mathrm{~kg}$ (N300) of pure nitrogen per hectare; $1 / 3$ of nitrogen was applied as seed fertilizer, with $2 / 3$ as top dressing, applied to the soil at the jointing stage. Fixed $\mathrm{P}$ and $\mathrm{K}\left(\mathrm{P}_{2} \mathrm{O}_{5} 150 \mathrm{~kg}\right.$ and $\left.\mathrm{K}_{2} \mathrm{O} 100 \mathrm{~kg} / \mathrm{ha}\right)$ were applied as seed fertilizer at one time. Sorghum was sown on May 15th, the trials area was $10 \mathrm{~m}$ long, consisting of eight ridges with a $0.65 \mathrm{~m}$ ridge distance and 300,000 seedlings per hectare, double row planting on ridge with row spacing of $15 \mathrm{~cm}$ and plant spacing of $10 \mathrm{~cm}$. Three replications were conducted (Fig. 2).

The mean maximum and minimum air temperatures and total rainfall during the cropping cycles (May to September) were 29.3 and $7.8^{\circ} \mathrm{C}$ and $357.4 \mathrm{~mm}$ for the year 2017 (Fig. 3).

\begin{tabular}{|c|c|c|c|c|c|c|c|}
\hline \multicolumn{7}{|c|}{1 Meter Experiment Protection Zone } \\
\hline Keza15 & Suiza7 & Keza15 & Suiza7 & Keza15 & Suiza7 & Keza15 & Suiza7 \\
N0 & N0 & N100 & N100 & N200 & N200 & N300 & N300 \\
\hline Suiza7 & Keza15 & Suiza7 & Keza15 & Suiza7 & Keza15 & Suiza7 & Keza15 \\
\hline N100 & N100 & N200 & N200 & N300 & N300 & N0 & N0 \\
\hline Keza15 & Suiza7 & Keza15 & Suiza7 & Keza15 & Suiza7 & Keza15 & Suiza7 \\
\hline N200 & N200 & N300 & N300 & N0 & N0 & N100 & N100 \\
\hline
\end{tabular}

Figure 2. The experimental design 


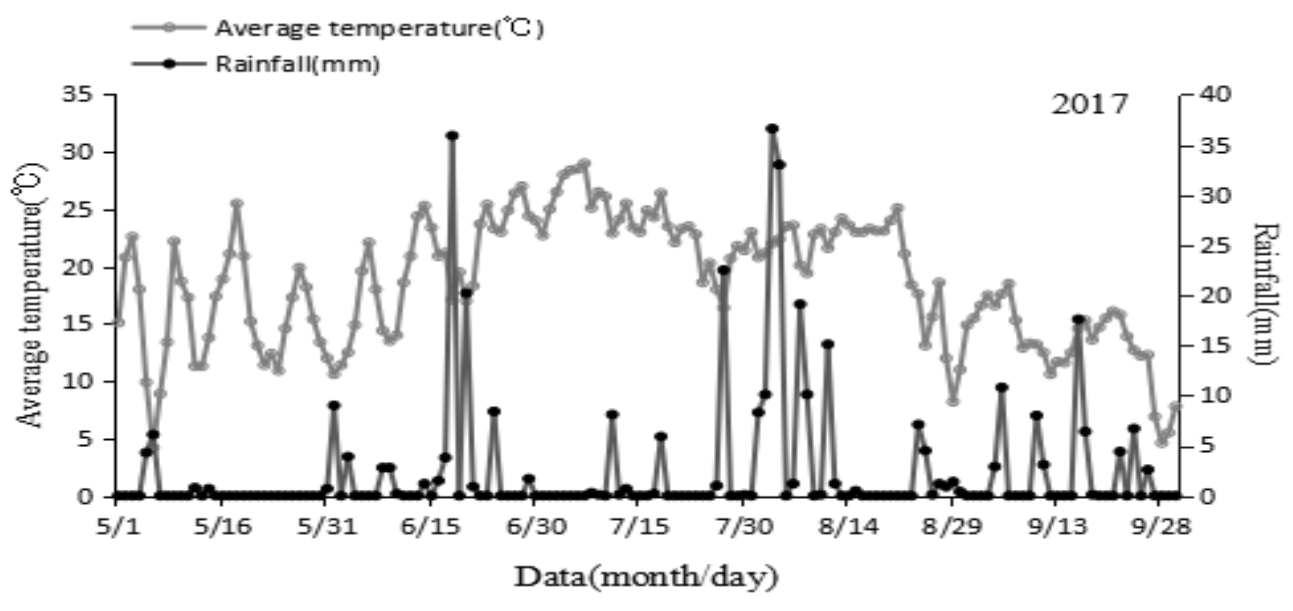

Figure 3. Average temperature and Rainfall duration during growth period in 2017

\section{Sample handling}

Plants of Growth uniformity were marked as samples, and the samples were taken on days 7 (August 5th), 14 (August 12th), 21 (August 19th), 28 (August 26th), 35 (September 2th) and 42 (September 9th) after the powder dispersed. Three spikes were taken each time from each treatment. Thirty grains were selected from the middle and upper parts of the spike and weighed. The seeds were frozen in liquid nitrogen and stored in an ultra-low temperature refrigerator at $-70{ }^{\circ} \mathrm{C}$. The rest of the seeds were killed at $105{ }^{\circ} \mathrm{C}$ and dried to constant weight at $80{ }^{\circ} \mathrm{C}$ for the determination of starch accumulation.

\section{Determination of starch accumulation}

Starch content determination according to the method of Fan Mingshun (Fan, et al., 2008). The main wavelength of the amylose content (\%) was $620 \mathrm{~nm}$, and the reference wavelength was $479 \mathrm{~nm}$. The main wavelength of the amylopectin content (\%) was $556 \mathrm{~nm}$, and the reference wavelength was $737 \mathrm{~nm}$. Both the amylose and amylopectin standard samples were obtained from the Heilongiiang Academy of Agricultural Sciences.

$$
\text { Total starch content }(\%)=\text { amy lose content }(\%)+\text { amy lopectin content }(\%) \text { (Eq.1) }
$$

\section{Determination of starch-related enzyme activity}

The activity of Soluble starch synthase (SSS), Starch branching enzyme (SBE), Bound starch synthetase (GBSS), Adenosine diphosphate glucose pyrophosphorylase (AGP), Uridine diphosphate glucose pyropitase activities (UGP) was determined by enzyme-linked immunosorbent assay. The kit was provided by Shanghai Enzymelinked Biology Co., Ltd. (Shanghai china), and the determination method was carried out according to the instructions. Three parallel measurements were made by the determination of the enzyme's activity.

\section{Yield measurement}

Grain yield and its composition: From each plot 20 plants (except from the guard area surrounding the plot) from one-meter-long ridge were harvested continuously at 
maturity for the determination of grain yield. The indexes included the single spike weight, grain number per spike and thousand kernel weight. The yield was converted by the weight at $14 \%$ water content.

\section{Analysis software and analysis method}

The data were processed by Excel 2013 and analyzed by SPSS 16.0 and data from each sampling data were analyzed separately. Means were separated by Duncan's multiple range test at $p<0.05$. The data are presented as the means \pm standard deviation from all replications. Different characters indicate significant differences.

\section{Results}

\section{Effect of nitrogen application on total starch content in grains}

It can be seen from Table 1 that the total starch content of the two sorghum varieties increased with the development of the growth period. The N0 treatment was significantly lower than each nitrogen treatment. The N0 treatment of Keza15 was significantly lower than that of $\mathrm{N}$ application, and there was no significant difference among $\mathrm{N}$ application treatments.

$7 \mathrm{~d}$ after powder dispersion, there was no significant difference in the total starch content of Suiza7 among $\mathrm{N}$ application treatments. From $14 \mathrm{~d}$ to $21 \mathrm{~d}$ after powder dispersion, $\mathrm{N} 200=\mathrm{N} 300>\mathrm{N} 100>\mathrm{N} 0$ and there was no significant difference between N200 and N300. From 28 d to 42 d after powder dispersion, $\mathrm{N} 200>\mathrm{N} 100=\mathrm{N} 300>\mathrm{N} 0$, there was no significant difference between N100 and N300.

Table 1. Effect of nitrogen application on total starch content in grains

\begin{tabular}{c|c|c|c|c|c|c|c}
\hline \multirow{3}{*}{ Cultivars } & \multirow{2}{*}{ Treatment } & \multicolumn{7}{|c}{ Total starch content (\%) } \\
\cline { 3 - 8 } & & $\begin{array}{c}\text { 7 d after } \\
\text { powder } \\
\text { dispersion }\end{array}$ & $\begin{array}{c}\text { 14 d after } \\
\text { powder } \\
\text { dispersion }\end{array}$ & $\begin{array}{c}\text { 21 d after } \\
\text { powder } \\
\text { dispersion }\end{array}$ & $\begin{array}{c}\text { 28 d after } \\
\text { powder } \\
\text { dispersion }\end{array}$ & $\begin{array}{c}\text { 35 d after } \\
\text { powder } \\
\text { dispersion }\end{array}$ & $\begin{array}{c}\text { 42 d after } \\
\text { powder } \\
\text { dispersion }\end{array}$ \\
\hline \multirow{3}{*}{ Keza15 } & N0 & $6.75 \pm 0.17 \mathrm{a}$ & $18.91 \pm 0.09 \mathrm{~b}$ & $38.07 \pm 0.38 \mathrm{c}$ & $50.97 \pm 1.40 \mathrm{~b}$ & $58.93 \pm 0.47 \mathrm{~b}$ & $63.36 \pm 0.51 \mathrm{~b}$ \\
& $\mathrm{~N} 100$ & $7.53 \pm 0.53 \mathrm{a}$ & $22.83 \pm 0.45 \mathrm{a}$ & $42.24 \pm 0.94 \mathrm{ab}$ & $55.07 \pm 0.26 \mathrm{a}$ & $64.05 \pm 0.91 \mathrm{a}$ & $68.83 \pm 0.42 \mathrm{a}$ \\
& $\mathrm{N} 200$ & $7.75 \pm 0.38 \mathrm{a}$ & $23.43 \pm 0.21 \mathrm{a}$ & $42.83 \pm 0.26 \mathrm{a}$ & $55.36 \pm 0.48 \mathrm{a}$ & $63.63 \pm 1.34 \mathrm{a}$ & $68.53 \pm 0.32 \mathrm{a}$ \\
& $\mathrm{N} 300$ & $7.57 \pm 0.41 \mathrm{a}$ & $22.88 \pm 0.24 \mathrm{a}$ & $40.68 \pm 0.52 \mathrm{~b}$ & $53.89 \pm 0.06 \mathrm{a}$ & $61.90 \pm 0.43 \mathrm{a}$ & $67.30 \pm 0.75 \mathrm{a}$ \\
\hline \multirow{5}{*}{ Suiza7 } & $\mathrm{N} 0$ & $6.38 \pm 0.31 \mathrm{~b}$ & $18.48 \pm 0.31 \mathrm{c}$ & $35.71 \pm 0.50 \mathrm{c}$ & $48.77 \pm 0.31 \mathrm{c}$ & $57.46 \pm 0.30 \mathrm{c}$ & $62.33 \pm 0.21 \mathrm{c}$ \\
& $\mathrm{N} 100$ & $7.75 \pm 0.47 \mathrm{a}$ & $22.06 \pm 0.13 \mathrm{~b}$ & $42.17 \pm 0.47 \mathrm{~b}$ & $54.98 \pm 0.37 \mathrm{~b}$ & $63.56 \pm 0.71 \mathrm{~b}$ & $68.32 \pm 0.25 \mathrm{~b}$ \\
& $\mathrm{~N} 200$ & $7.96 \pm 0.38 \mathrm{a}$ & $24.12 \pm 0.36 \mathrm{a}$ & $44.89 \pm 0.47 \mathrm{a}$ & $56.75 \pm 0.28 \mathrm{a}$ & $66.61 \pm 0.61 \mathrm{a}$ & $69.86 \pm 0.39 \mathrm{a}$ \\
& $\mathrm{N} 300$ & $7.68 \pm 0.10 \mathrm{a}$ & $23.81 \pm 0.37 \mathrm{a}$ & $43.94 \pm 0.12 \mathrm{a}$ & $55.35 \pm 0.22 \mathrm{~b}$ & $62.97 \pm 0.17 \mathrm{~b}$ & $67.91 \pm 0.46 \mathrm{~b}$ \\
\hline
\end{tabular}

Different letters indicate significant differences according to Duncan's test $(p \leq 0.05)$

\section{Effect of nitrogen application on the amylopectin content in grains}

The result showed that the amylopectin content of the two varieties of sorghum increased significantly from $7 \mathrm{~d}$ to $42 \mathrm{~d}$ after powder dispersion, and the amylopectin content of the nitrogen treatment was significantly higher than that of the N0 treatment (Table 2). There was no significant difference among nitrogen treatments with respect 
to the amylopectin content in Keza15 on the 7 days after powder dispersal; $\mathrm{N} 100=\mathrm{N} 200>\mathrm{N} 300=\mathrm{N} 0$ on the 21 days after powder dispersal, there was no significant difference between $\mathrm{N} 100$ and $\mathrm{N} 200 ; \mathrm{N} 200=\mathrm{N} 100=\mathrm{N} 300>\mathrm{N} 0$ on the 28 days after powder dispersal, there was no significant difference between N100 and N200.

There was no significant difference between N0, N100 and N200 in the amylopectin content of Suiza 7 on the 7 days after powder dispersion. From 14 to 28 days after powder dispersal, N300 $=\mathrm{N} 200=\mathrm{N} 100>\mathrm{N} 0$, and 42 days after powder dispersal, there was a significant difference between the N0 treatment and the nitrogen treatment.

Table 2. Effect of nitrogen application on the amylopectin content in grains

\begin{tabular}{c|c|c|c|c|c|c|c}
\hline \multirow{3}{*}{ Cultivars } & \multirow{2}{*}{ Treatment } & \multicolumn{7}{|c}{$\begin{array}{c}\text { Amylopectin content (\%) } \\
\text { powder } \\
\text { dispersion }\end{array}$} & $\begin{array}{c}\text { 14 d after } \\
\text { powder } \\
\text { dispersion }\end{array}$ & $\begin{array}{c}\text { 21 d after } \\
\text { powder } \\
\text { dispersion }\end{array}$ & $\begin{array}{c}\mathbf{2 8 ~ d} \text { after } \\
\text { powder } \\
\text { dispersion }\end{array}$ & $\begin{array}{c}\text { 35 d after } \\
\text { powder } \\
\text { dispersion }\end{array}$ & $\begin{array}{c}\mathbf{4 2} \text { d after } \\
\text { powder } \\
\text { dispersion }\end{array}$ \\
\hline \multirow{5}{*}{ Keza15 } & N0 & $4.02 \pm 0.08 \mathrm{a}$ & $14.02 \pm 0.28 \mathrm{~b}$ & $31.00 \pm 0.07 \mathrm{~b}$ & $40.98 \pm 0.95 \mathrm{~b}$ & $46.86 \pm 0.56 \mathrm{~b}$ & $49.47 \pm 0.32 \mathrm{~b}$ \\
& $\mathrm{~N} 100$ & $4.42 \pm 0.31 \mathrm{a}$ & $16.63 \pm 0.30 \mathrm{a}$ & $32.69 \pm 0.28 \mathrm{a}$ & $43.03 \pm 0.13 \mathrm{a}$ & $50.19 \pm 1.06 \mathrm{a}$ & $53.36 \pm 0.16 \mathrm{a}$ \\
& $\mathrm{N} 200$ & $4.43 \pm 0.28 \mathrm{a}$ & $17.07 \pm 0.04 \mathrm{a}$ & $32.76 \pm 0.31 \mathrm{a}$ & $43.18 \pm 0.24 \mathrm{a}$ & $49.48 \pm 1.22 \mathrm{ab}$ & $53.40 \pm 0.59 \mathrm{a}$ \\
& $\mathrm{N} 300$ & $4.39 \pm 0.31 \mathrm{a}$ & $17.03 \pm 0.04 \mathrm{a}$ & $31.54 \pm 0.25 \mathrm{~b}$ & $42.16 \pm 0.16 \mathrm{ab}$ & $48.95 \pm 0.09 \mathrm{ab}$ & $52.82 \pm 0.20 \mathrm{a}$ \\
\hline \multirow{5}{*}{ Suiza7 } & $\mathrm{N} 0$ & $3.90 \pm 0.05 \mathrm{~b}$ & $13.67 \pm 0.28 \mathrm{c}$ & $28.88 \pm 0.29 \mathrm{c}$ & $39.72 \pm 0.31 \mathrm{c}$ & $45.73 \pm 0.32 \mathrm{c}$ & $49.15 \pm 0.24 \mathrm{~b}$ \\
& $\mathrm{~N} 100$ & $4.51 \pm 0.31 \mathrm{ab}$ & $16.05 \pm 0.11 \mathrm{~b}$ & $32.72 \pm 0.28 \mathrm{~b}$ & $43.04 \pm 0.48 \mathrm{~b}$ & $49.78 \pm 0.35 \mathrm{~b}$ & $53.05 \pm 0.52 \mathrm{a}$ \\
& $\mathrm{N} 200$ & $4.62 \pm 0.26 \mathrm{ab}$ & $17.88 \pm 0.07 \mathrm{a}$ & $34.54 \pm 0.33 \mathrm{a}$ & $44.71 \pm 0.30 \mathrm{a}$ & $51.64 \pm 0.63 \mathrm{a}$ & $54.19 \pm 0.43 \mathrm{a}$ \\
& $\mathrm{N} 300$ & $4.67 \pm 0.11 \mathrm{a}$ & $18.14 \pm 0.05 \mathrm{a}$ & $34.57 \pm 0.23 \mathrm{a}$ & $44.24 \pm 0.20 \mathrm{a}$ & $49.82 \pm 0.20 \mathrm{~b}$ & $53.71 \pm 0.45 \mathrm{a}$ \\
\hline
\end{tabular}

Different letters indicate significant differences according to Duncan's test $(\mathrm{p} \leq 0.05)$

\section{Effect of nitrogen application on the amylose content in grains}

The results show that the amylose content of the two varieties increased with the development of growth (Table 3). The N0 treatment was significantly lower than the nitrogen treatment. 35 days after the powder dispersal of Keza15, compared with other treatments, the amylose content of N0 and N300 decreased significantly, but the difference between the $\mathrm{N} 0$ and $\mathrm{N} 300$ treatments was no significant. 42 days after powder dispersion, there was no significant difference between N200 and N300, but compared with N100 treatments, the amylose content of N200 and N300 decreased significantly.

At 7-14 days after the powder dispersal of suiza7, there was no significant difference in the content of the amylose between N100 and N200, which was significantly higher than that between $\mathrm{N} 0$ and N300. 21 and 35 days after powder dispersion, there was no significant difference in the amylose content between N100 and N300, but there was a significant difference between $\mathrm{N} 100$ and N200. There was no significant difference between N100 and N200 treatments at $28 \mathrm{~d}$ and $42 \mathrm{~d}$ after powder dispersion, which was significantly higher than the other treatments.

\section{Effects of nitrogen application on the yield and components of sorghum}

From the analysis results shown in Table 4, it can be seen that there was a significant positive correlation between the number of grains per spike and the 1000-grain weight of the two sorghum varieties. Within a certain range, the number of grains per spike and 
the 1000-grain weight of the two sorghum varieties increased with the increase of the nitrogen application amount, but when the nitrogen exceeded the N200 level, the number of grains per spike and the 1000-grain weight did not continue to increase and began to decline. From the analysis of the grain number per spike and the 1000-grain weight, the best nitrogen application amount was N200. The yield of sorghum increased first and then decreased with the increase in nitrogen application. The yield response of different sorghum genotypes to nitrogen was different. The yield of Keza15 was $\mathrm{N} 100=\mathrm{N} 200>\mathrm{N} 300>\mathrm{N} 0$, and there was no significant difference between the N100 and N200 treatments. The yield of Suiza7 was N200 > N100 > N300 > N0 among the treatments, and there was a significant difference among the treatments.

Table 3. Effect of nitrogen application on the amylose content in grains

\begin{tabular}{c|c|c|c|c|c|c|c}
\hline & & \multicolumn{7}{|c}{ Amylose content (\%) } \\
\cline { 3 - 8 } Cultivars & Treatment & $\begin{array}{c}\text { 7 d after } \\
\text { powder } \\
\text { dispersion }\end{array}$ & $\begin{array}{c}\text { 14 d after } \\
\text { powder } \\
\text { dispersion }\end{array}$ & $\begin{array}{c}\text { 21 d after } \\
\text { powder } \\
\text { dispersion }\end{array}$ & $\begin{array}{c}\mathbf{2 8} \text { d after } \\
\text { powder } \\
\text { dispersion }\end{array}$ & $\begin{array}{c}\text { 35 d after } \\
\text { powder } \\
\text { dispersion }\end{array}$ & $\begin{array}{c}\text { 42 d after } \\
\text { powder } \\
\text { dispersion }\end{array}$ \\
\hline \multirow{5}{*}{ Keza15 } & N0 & $2.73 \pm 0.19 \mathrm{a}$ & $4.89 \pm 0.21 \mathrm{~b}$ & $7.07 \pm 0.33 \mathrm{~b}$ & $9.98 \pm 0.49 \mathrm{~b}$ & $12.06 \pm 0.09 \mathrm{c}$ & $13.89 \pm 0.22 \mathrm{~b}$ \\
& $\mathrm{~N} 100$ & $3.11 \pm 0.26 \mathrm{a}$ & $6.21 \pm 0.18 \mathrm{a}$ & $9.55 \pm 0.74 \mathrm{a}$ & $12.03 \pm 0.13 \mathrm{a}$ & $13.86 \pm 0.16 \mathrm{ab}$ & $15.47 \pm 0.33 \mathrm{a}$ \\
& $\mathrm{N} 200$ & $3.32 \pm 0.14 \mathrm{a}$ & $6.36 \pm 0.23 \mathrm{a}$ & $10.07 \pm 0.54 \mathrm{a}$ & $12.18 \pm 0.24 \mathrm{a}$ & $14.15 \pm 0.37 \mathrm{a}$ & $15.13 \pm 0.27 \mathrm{ab}$ \\
& $\mathrm{N} 300$ & $3.18 \pm 0.14 \mathrm{a}$ & $5.85 \pm 0.21 \mathrm{a}$ & $9.13 \pm 0.38 \mathrm{a}$ & $11.73 \pm 0.14 \mathrm{a}$ & $12.95 \pm 0.50 \mathrm{bc}$ & $14.49 \pm 0.60 \mathrm{ab}$ \\
\hline \multirow{5}{*}{ Suiza7 } & $\mathrm{N} 0$ & $2.48 \pm 0.27 \mathrm{~b}$ & $4.81 \pm 0.30 \mathrm{~b}$ & $6.83 \pm 0.34 \mathrm{c}$ & $9.05 \pm 0.08 \mathrm{c}$ & $11.73 \pm 0.28 \mathrm{c}$ & $13.19 \pm 0.13 \mathrm{c}$ \\
& $\mathrm{N} 100$ & $3.24 \pm 0.17 \mathrm{a}$ & $6.01 \pm 0.23 \mathrm{a}$ & $9.45 \pm 0.21 \mathrm{~b}$ & $11.94 \pm 0.11 \mathrm{a}$ & $13.78 \pm 0.35 \mathrm{~b}$ & $15.27 \pm 0.29 \mathrm{a}$ \\
& $\mathrm{N} 200$ & $3.34 \pm 0.23 \mathrm{a}$ & $6.24 \pm 0.29 \mathrm{a}$ & $10.35 \pm 0.26 \mathrm{a}$ & $12.04 \pm 0.08 \mathrm{a}$ & $14.97 \pm 0.09 \mathrm{a}$ & $15.67 \pm 0.08 \mathrm{a}$ \\
& $\mathrm{N} 300$ & $3.01 \pm 0.02 \mathrm{ab}$ & $5.68 \pm 0.33 \mathrm{ab}$ & $9.37 \pm 0.16 \mathrm{~b}$ & $11.11 \pm 0.40 \mathrm{~b}$ & $13.15 \pm 0.17 \mathrm{~b}$ & $14.20 \pm 0.16 \mathrm{~b}$ \\
\hline
\end{tabular}

Different letters indicate significant differences according to Duncan's test $(\mathrm{p} \leq 0.05)$

Table 4. Effect of nitrogen level on yield and components of sorghum

\begin{tabular}{c|c|c|c|c|c}
\hline Cultivars & $\begin{array}{c}\text { Treatment } \\
\left(\mathbf{k g} \cdot \mathbf{h m}^{-2}\right)\end{array}$ & $\begin{array}{c}\text { Grain number } \\
\text { per spike }(\mathbf{L i})\end{array}$ & $\begin{array}{c}\text { Thousand grain } \\
\text { weight }(\mathbf{g})\end{array}$ & $\begin{array}{c}\text { Single spike } \\
\text { weight }(\mathbf{g})\end{array}$ & Yield $\left(\mathbf{k g} \cdot \mathbf{h m}^{-\mathbf{2}}\right)$ \\
\hline \multirow{3}{*}{ Keza15 } & N0 & $1018.00 \pm 10.21 \mathrm{~b}$ & $20.34 \pm 0.45 \mathrm{~b}$ & $30.18 \pm 0.52 \mathrm{~b}$ & $6210.82 \pm 75.92 \mathrm{c}$ \\
& $\mathrm{N} 100$ & $1087.70 \pm 16.41 \mathrm{a}$ & $25.37 \pm 0.58 \mathrm{a}$ & $37.14 \pm 1.25 \mathrm{a}$ & $8278.23 \pm 61.97 \mathrm{a}$ \\
& $\mathrm{N} 200$ & $1069.30 \pm 6.39 \mathrm{a}$ & $25.76 \pm 0.58 \mathrm{a}$ & $37.85 \pm 0.86 \mathrm{a}$ & $8262.74 \pm 89.85 \mathrm{a}$ \\
& $\mathrm{N} 300$ & $1002.00 \pm 4.51 \mathrm{~b}$ & $25.28 \pm 0.41 \mathrm{a}$ & $35.93 \pm 0.67 \mathrm{a}$ & $7600.17 \pm 64.28 \mathrm{~b}$ \\
\hline \multirow{3}{*}{ Suiz7 } & N0 & $948.00 \pm 17.79 \mathrm{~b}$ & $19.35 \pm 0.33 \mathrm{~b}$ & $31.75 \pm 1.55 \mathrm{~b}$ & $5504.09 \pm 62.60 \mathrm{~d}$ \\
& $\mathrm{~N} 100$ & $1074.00 \pm 21.66 \mathrm{a}$ & $25.11 \pm 0.28 \mathrm{a}$ & $37.22 \pm 0.82 \mathrm{a}$ & $8091.52 \pm 140.98 \mathrm{~b}$ \\
& $\mathrm{~N} 200$ & $1086.30 \pm 6.44 \mathrm{a}$ & $25.95 \pm 0.65 \mathrm{a}$ & $37.35 \pm 1.10 \mathrm{a}$ & $8457.11 \pm 61.32 \mathrm{a}$ \\
& $\mathrm{N} 300$ & $993.00 \pm 4.00 \mathrm{~b}$ & $25.27 \pm 0.45 \mathrm{a}$ & $33.56 \pm 1.06 \mathrm{ab}$ & $7527.93 \pm 86.88 \mathrm{c}$ \\
\hline
\end{tabular}

Different letters indicate significant differences according to Duncan's test $(\mathrm{p} \leq 0.05)$

\section{The correlation between nitrogen application and starch content}

The results showed that the correlation among nitrogen and total starch, amylopectin content varies with varieties (Table 5). There was a significant positive correlation between nitrogen application and total starch, amylopectin content on the 14 days after powder dispersal, and a significant positive correlation between the nitrogen level and the content of Amylose on the 28 days after powder dispersal. There was no significant 
correlation between nitrogen application and starch of Keza15 in other periods. However, there was a significant positive correlation among nitrogen application and total starch, amylopectin content of Suiza7 from 7 to 42 days after powder dispersal, and the amylose content 21 days after powder dispersal. There was a significant positive correlation between nitrogen and amylose content 21 days after powder dispersal. The correlation coefficients of the two sorghum varieties were $14 \mathrm{~d}>21 \mathrm{~d}>28 \mathrm{~d}>42 \mathrm{~d}>35 \mathrm{~d}>7 \mathrm{~d}$ after powder dispersal.

Table 5. The coefficients of nitrogen levels and starch content

\begin{tabular}{|c|c|c|c|c|c|c|c|}
\hline Cultivars & $\begin{array}{c}\text { Treatment } \\
\left(\mathrm{kg} \cdot \mathrm{hm}^{-2}\right)\end{array}$ & $\begin{array}{c}7 \text { d after } \\
\text { powder } \\
\text { dispersion }\end{array}$ & $\begin{array}{l}14 \text { d after } \\
\text { powder } \\
\text { dispersion }\end{array}$ & $\begin{array}{c}21 \text { dafter } \\
\text { powder } \\
\text { dispersion }\end{array}$ & $\begin{array}{l}28 \text { d after } \\
\text { powder } \\
\text { dispersion }\end{array}$ & $\begin{array}{c}35 \mathrm{~d} \text { after } \\
\text { powder } \\
\text { dispersion }\end{array}$ & $\begin{array}{c}42 \mathrm{~d} \text { after } \\
\text { powder } \\
\text { dispersion }\end{array}$ \\
\hline \multirow{3}{*}{ Keza 15} & $\begin{array}{c}\text { Total starch } \\
\text { content }\end{array}$ & 0.443 & $0.755^{* *}$ & 0.466 & 0.497 & 0.402 & 0.559 \\
\hline & $\begin{array}{c}\text { Amylose } \\
\text { content }\end{array}$ & 0.512 & 0.525 & 0.552 & $0.619^{*}$ & 0.351 & 0.200 \\
\hline & $\begin{array}{l}\text { Amylopectin } \\
\text { content }\end{array}$ & 0.306 & $0.816^{* *}$ & 0.230 & 0.365 & 0.358 & $0.661^{*}$ \\
\hline \multirow{3}{*}{ Suiza 7} & $\begin{array}{c}\text { Total starch } \\
\text { content }\end{array}$ & $0.584 *$ & $0.884 * *$ & $0.844 * *$ & $0.776 * *$ & $0.649 *$ & $0.707^{*}$ \\
\hline & $\begin{array}{l}\text { Amylose } \\
\text { content }\end{array}$ & 0.437 & 0.464 & $0.700 *$ & 0.566 & 0.501 & 0.383 \\
\hline & $\begin{array}{l}\text { Amylopectin } \\
\text { content }\end{array}$ & $0.632 *$ & $0.946 * *$ & $0.898 * *$ & $0.849 * *$ & $0.706^{*}$ & $0.797 * *$ \\
\hline
\end{tabular}

$\mathrm{NS}, *, * *$ No significance or significant at $\mathrm{p} \leq 0.05,0.01$

\section{Correlation between starch content and yield}

It can be seen from Table 6 that there was a significant positive correlation between the total starch content, amylose content and 1000-grain weight, the number of grains per spike and the yield of Keza15, and a significant positive correlation between the amylopectin content and 1000-grain weight and yield. There was a significant positive correlation between the starch content and the number of grains per spike, 1000-grain weight and yield. Therefore, it can be seen that the correlation between starch and grain number per spike, 1000-grain weight and yield varies with genotypes, and the correlation coefficient of the low-N-sensitive varieties is higher than that of the low-Ntolerant varieties.

\section{Effect of nitrogen application on the activity of SSS in grains}

The change of SSS activity was shown in Figure 4. The activity of SSS of Keza15 and Suiza7 increased significantly on the 14th day, peaked on the 28th day, and decreased significantly on the 42nd day. The treatment of N200 and N300 of two sorghum varieties kept at a high level from 14 to 35 days after powder dispersal. During this period, the increase in SSS activity determined the synthesis ability of sorghum starch, which had a great impact on the starch content of sorghum.

There was no significant difference between the N200 and N300 treatments of Keza15 at 7-35 d after powder dispersion, but there was significant difference at 42 days after powder dispersion. 
Table 6. The coefficients between starch content and production

\begin{tabular}{c|c|c|c|c}
\hline Cultivars & Starch content & $\begin{array}{c}\text { Grain number per } \\
\text { spike (Li) }\end{array}$ & $\begin{array}{c}\text { Thousand grain } \\
\text { weight }(\mathbf{g})\end{array}$ & Yield $\left(\mathbf{k g} \cdot \mathbf{h m} \mathbf{- 2}^{\mathbf{2}}\right)$ \\
\hline \multirow{3}{*}{ Keza 15 } & Total starch content & $0.628^{*}$ & $0.927 * *$ & $0.912^{* *}$ \\
& Amylose content & $0.687 *$ & $0.751^{* *}$ & $0.661 *$ \\
& Amylopectin content & 0.521 & $0.894 * *$ & $0.918^{* *}$ \\
\hline \multirow{3}{*}{ Suiza 7 } & Total starch content & $0.818^{* *}$ & $0.962^{* *}$ & $0.970^{* *}$ \\
& Amylose content & $0.850 * *$ & $0.792^{* *}$ & $0.901 * *$ \\
& Amylopectin content & $0.727 * *$ & $0.954 * *$ & $0.913^{* *}$ \\
\hline
\end{tabular}

$\mathrm{NS}, *, * *$ : No significance or significant at $\mathrm{p} \leq 0.05,0.01$

The activity of SSS of Suiza7 was N300 > N200 > N100 > N0 on the 7 days after powder dispersal, and there were significant differences among the treatments. On the 14th, 21st and 35th day after powder dispersal, the difference between N300 and N200 treatment was significant compared with N100 treatment.
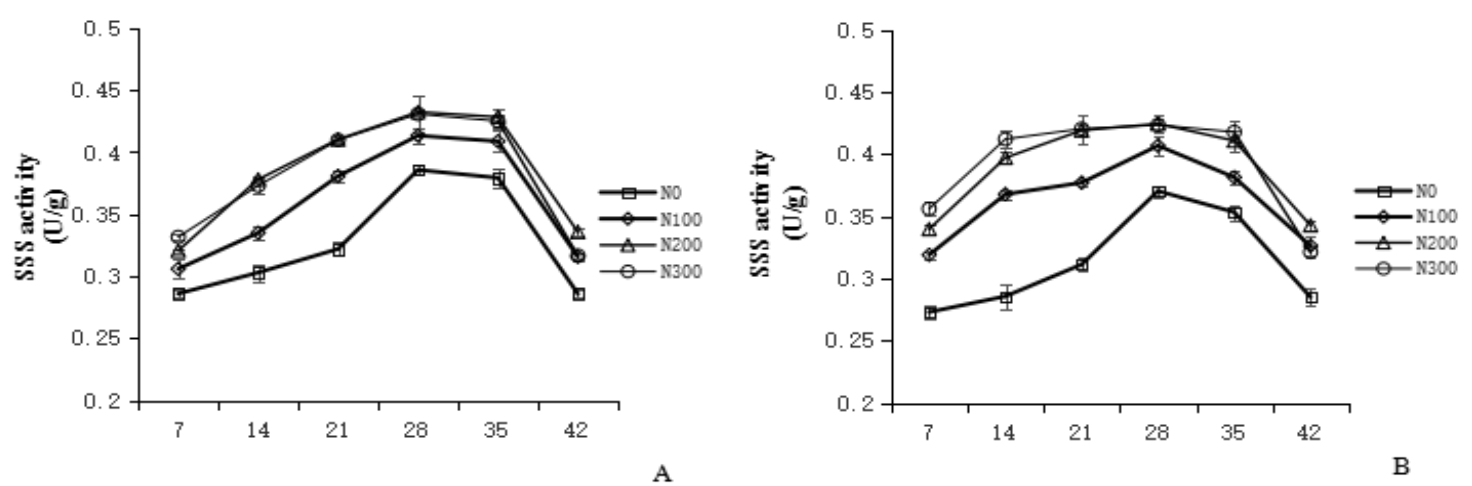

Figure 4. (A) Effect of nitrogen application on the activity of SSS in grains of Keza15. (B) Effect of nitrogen application on the activity of SSS in grains of Suiza7. Error bars represent \pm S.E. of the mean

\section{Effect of nitrogen application on the activity of SBE in grains}

The results in Figure 5 showed that SBE activity of two sorghum varieties with different genotypes increased first and then decreased with the advancement of grain development. It reached a peak value 28 days after powder dispersal and then began to decline. The difference between N0 and the other three treatments was very significant.

The SBE activity of Keza15 was higher at the N200 treatment from 7 to 42 days after powder dispersal. The SBE activity of the N200 and N300 treatments was significantly higher than that of the N100 treatment at 7-28 days after powder dispersal, there was no significant difference between N200 and N300. At 35-42 d, N100 and N200 were significantly higher than N300.

The SBE activity of Suiza7 was significantly increased 14 days after powder dispersion, reached the peak value 28 days after powder dispersion, and significantly decreased 35 days after powder dispersion. The SBE activity was the highest at the N300 level from 7 to 35 days after powder dispersion and was the highest at the N200 level 42 days after powder dispersion. 


\section{Effect of nitrogen application on the activity of GBSS in grains}

The results shown in Figure 6 demonstrated that the GBSS activity of the two varieties of sorghum from 7 to 42 days after powder dispersal showed a single peak curve change of first increasing and then decreasing, and there was no significant difference between the GBSS activity value $42 \mathrm{~d}$ after powder dispersal and $7 \mathrm{~d}$ after powder dispersal. The N0 treatment was significantly lower than the other three treatments, indicating that low nitrogen could significantly reduce GBSS activity.
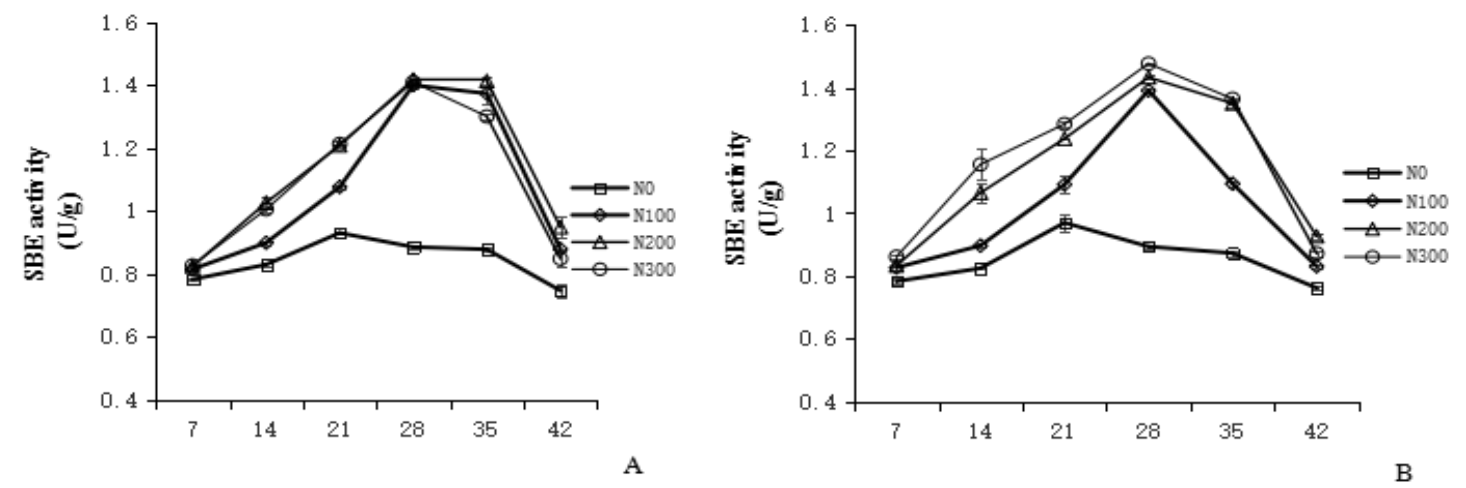

Figure 5. (A) Effect of nitrogen application on the activity of SBE in grains of Keza15. (B) Effect of nitrogen application on the activity of SBE in grains of Suiza7. Error bars represent $\pm S$.E. of the mean

At the level of N0, the GBSS activity of Keza15 reached the peak value 35 days after powder dispersion, and at the level of N100 and N300, the GBSS activity reached the peak value 28 days after powder dispersion and then began to decrease significantly. At the level of N200, the activity of GBSS increased significantly 14 days after powder dispersal, peaked 35 days after powder dispersal, and decreased significantly 42 days after powder dispersal.

At the N0 level, the GBSS activity of Suiza7 reached its peak at $28 \mathrm{~d}$ after powder dispersal; At the N100 level, GBSS reached the peak value 28 days after powder dispersal; At the N200 and N300 levels, GBSS reached the peak value 21 days later powder dispersal, and then began to decrease significantly.
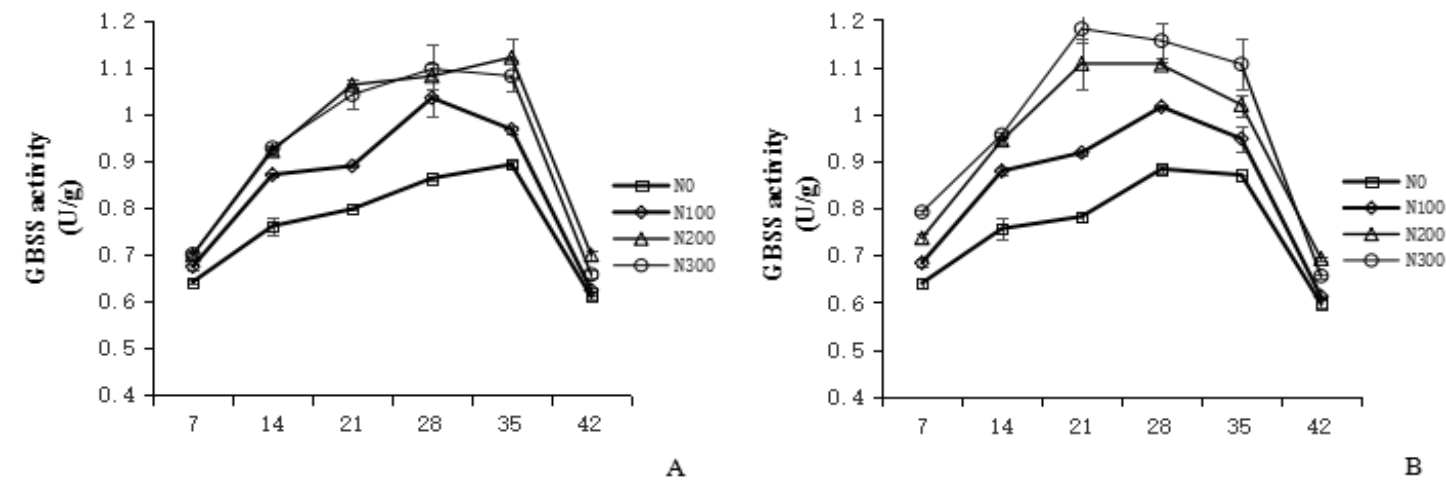

Figure 6. (A) Effect of nitrogen application on the activity of GBSS in grains of Keza15. (B) Effect of nitrogen application on the activity of GBSS in grains of Suiza7. Error bars represent $\pm S$.E. of the mean 


\section{The effect of nitrogen application on the activity of AGP in grains}

From the analysis of Figure 7, it can be seen that the AGP activity of the two sorghum varieties increased first and then decreased with the development of the growth process and grain development, and the AGP activity of the N0 treatment was significantly lower than that of the other three treatments, indicating that the AGP activity of the low nitrogen treatment would be significantly reduced.

At the level of N100, N200 and N300, the AGP activity of Keza15 reached its peak at $35 \mathrm{~d}$ after powder dispersion, and decreased significantly at $42 \mathrm{~d}$ after powder dispersion.

At the N100 level of Suiza7, the AGP activity was significantly increased 21 days after powder dispersion, reached the peak value 28 days after powder dispersion, and began to decrease 35 days after powder dispersion. At the level of N200 and N300, AGP activity increased significantly at 14 days after powder dispersion, peaked at 28 days after powder dispersion, and decreased significantly at 35 days after powder dispersion. The response of different genotypes to AGP activity was different. The peak value of Keza15 was reached 35 days after powdering, and Suiza7 was advanced to 28 days. The increasing range of AGP activity between the N200 and N300 treatment and the N0 treatment of Suiza7 was significantly higher than that of Keza15.
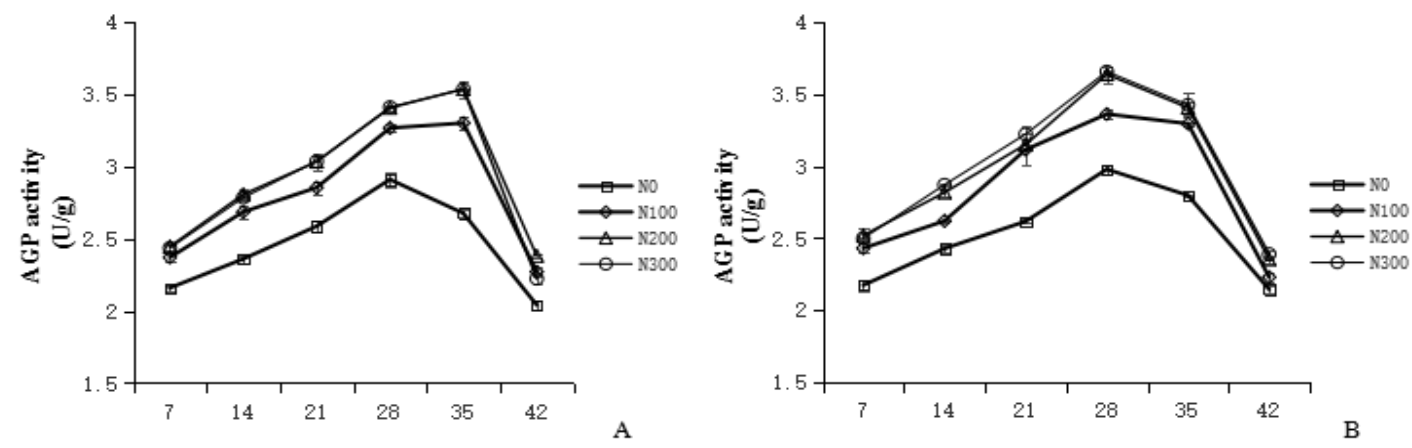

Figure 7. (A) Effect of nitrogen application on the activity of AGP in grains of Keza15. (B) Effect of nitrogen application on the activity of AGP in grains of Suiza7. Error bars represent $\pm S$.E. of the mean

\section{Effect of nitrogen application on the activity of UGP in grains}

The results of Figure 8 showed that the UGP activity of the two varieties of sorghum increased first and then decreased from 7 to 42 days after powder dispersion. The UGP activity of nitrogen application was higher than that of $\mathrm{N} 0$ in each period after powder dispersal. Under the level of N0, the UGP activity of Keza15 and Suiza7 increased significantly 21 days after powder dispersal, reached the peak 28 days after powder dispersal, and decreased significantly 42 days after powder dispersal.

At the N100 level, Keza15 reached the peak value 35 days after powder dispersal; at the N200 and N300 levels, at 28 days and 42 days after powder dispersal, the activity value of UGP was significantly lower than that at 7 days after powder dispersal.

At the N100 level, Suiza7 reached its peak at 28 days after powder dispersion and decreased significantly at 35 days after powder dispersion. At the level of N200 and $\mathrm{N} 300$, the peak value was reached at 28 days after powder dispersal and decreased significantly at 35 days after powder dispersal. 

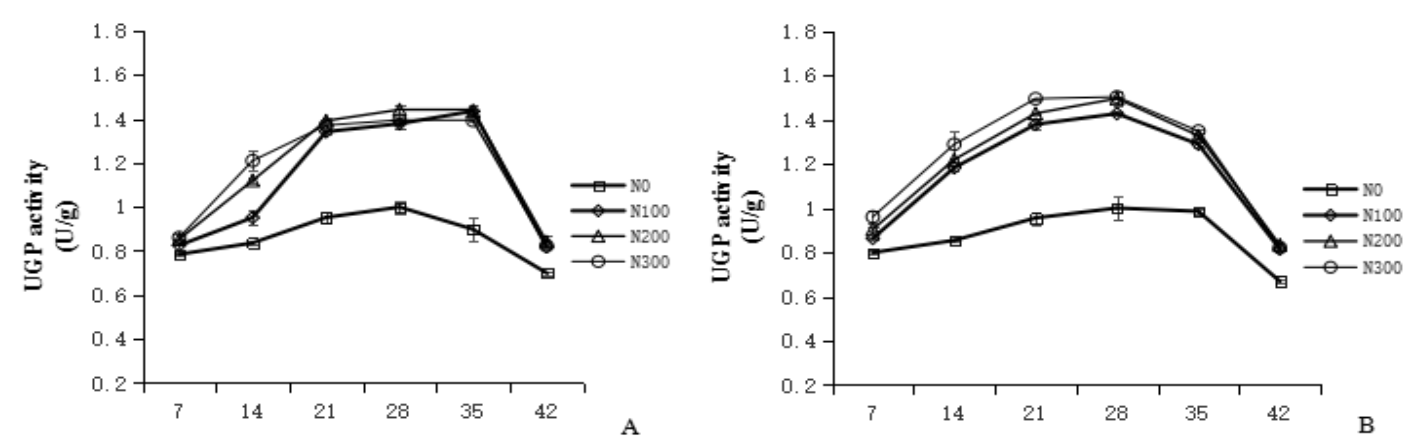

Figure 8. (A) Effect of nitrogen application on the activity of UGP in grains of Keza15. (B) Effect of nitrogen application on the activity of UGP in grains of Suiza7. Error bars represent $\pm S . E$. of the mean

\section{Discussion}

Effect of nitrogen application on starch accumulation and related enzyme activities in the grain of high-density planting sorghum

Starch is an important energy storage material of plants, its content and quality will directly affect the yield and economic value of crops. There was a significant positive correlation between the amount of nitrogen application and the yield of total starch, amylopectin and amylose in a proper range, but nitrogen application played an opposite role when it exceeded a certain level (Wang et al., 2006). The starch content increased with the increase in nitrogen application in a certain range, and there were differences among varieties (Zhao et al., 2003). The results showed that there was a great change in the total starch content in the nitrogen-sensitive varieties compared with the low nitrogen-tolerant varieties, and the difference between the treatment of Suiza7 N0 and each nitrogen application was significantly higher than that of Keza15. From 7 to 21 days after powder dispersal, the starch of the two sorghum varieties increased greatly, which was the rapid growth period of starch accumulation, and played an important role in the starch synthesis of grains. The content of amylopectin increased with the development of sorghum varieties with different genotypes. The amylose content of the two different sorghum varieties reached the peak value under the N200 treatment, and that of the N0 treatment was lower than that of the other nitrogen treatments. There was no significant difference among the nitrogen treatments of Keza15, but from 21 days after the powder dispersal of Suiza7, the N300 treatment was significantly lower than the N200 treatment, which indicated that high nitrogen was disadvantageous to amylose accumulation of nitrogen-sensitive varieties.

The AGP activity, SSS activity and GBSS activity were significantly related to the amount of nitrogen applied in the later stage. ADPG pyrophosphorylase is the key enzyme that controls the rate of starch accumulation, and starch-branching enzyme is the key enzyme that affects the synthesis of amylopectin (Li et al., 2005). It is as important in the process of grain filling as ADPG pyrophosphorylase (Kouich et al., 1992; Yang et al., 2005). The activity of SSS, SBE, GBSS, AGP and UGP increased first and then decreased with the development of grain. The results showed that the application of nitrogen was beneficial to the activity of the four enzymes, but too much of application nitrogen would lead to a decrease, which indicated that nitrogen had an important regulatory effect on the four enzymes. In this study, the NO treatment was 
significantly lower than each nitrogen application, indicating that nitrogen application promoted the activity of SSS. The GBSS activity of N-sensitive sorghum was earlier than that of low-N-tolerant sorghum. The increase of GBSS activity of the $\mathrm{N}$-sensitive sorghum in the low-N treatment was higher than that of the low-N-tolerant sorghum, and the AGP activity in the low-N treatment was significantly reduced. The results showed that the AGP activity of low-N-tolerant varieties was slower than that of nitrogen-sensitive varieties, which indicated that different varieties needed different nitrogen amounts, which is consistent with other research (Li et al., 2005; Tan et al., 2016).

\section{Effect of nitrogen application on Yield of sorghum with different genotypes}

The increase of corn yield by nitrogen application mainly depends on the number of grains per spike and 1000-grain weight (Yang et al., 2008). The proper application of nitrogen fertilizer could speed up grain filling rate, and too high or too low application of nitrogen fertilizer would reduce grain weight (He et al., 2005). Nitrogen fertilizer helps the decomposition of soil organic matter, promotes the absorption of nutrients by sorghum, and improves the small environment of sorghum root area (Ni et al., 2016). The application of nitrogen increased the number of spikes per unit and the grain weight, but the excessive application of nitrogen had the opposite effect on the grain weight (Sun et al., 2008). The results showed that the yield of the two sorghum varieties with different genotypes increased first and then decreased with the increase in nitrogen application. The maximum yield of Suiza7 was in the N200 treatment, and that of Keza15 was in the N100 treatment. Suiza7 was $2.16 \%$ higher than that of Keza15, which indicated that Suiza7 had a higher yield than that of the low-N-tolerant variety under the condition of sufficient nitrogen fertilizer. There were significant differences in yield between the treatments of Suiza7; the difference between N200 and N0 was 53.65\%, the difference of Keza15 between N100 and N200 was not significant, and the difference between N100 and N0 was $33.3 \%$, which indicated that the yield of the low-N-sensitive variety increased more than that of low-N-tolerant variety, and nitrogen absorption and utilization were more efficient. Nitrogen had a significant positive correlation with the number of grains per spike and the 1000-grain weight of the two sorghum varieties. When nitrogen exceeded N200, the number of grains per spike and 1000-grain weight no longer increased and began to decrease. The spike weight had the strongest direct relationship with the number of grains per spike, followed by the 1000-grain weight.

\section{Conclusion}

The response of the low- $\mathrm{N}$-sensitive varieties to nitrogen was faster than that of the low-N-tolerant varieties. Under the condition of low nitrogen, the absorption and utilization of nitrogen by amylopectin of the low-N-sensitive varieties were lower than that of the low-N-tolerant varieties.

Nitrogen application is beneficial for the increase of SSS, SBE, GBSS, AGP and UGP activities, but the excessive application of nitrogen will lead to a decrease. The best nitrogen application amount was $200 \mathrm{~kg} \mathrm{~N} \mathrm{ha}^{-1}$ (N200) to achieve the highest yield. Therefore, it can be concluded that N200 is optimal nitrogen application for the production potential under high plant density for sorghum production in northern China, whereas insufficient or excessive nitrogen application will lead to the decrease of starch content. 
Acknowledgements. This research was supported by the China Agriculture Research System (CARS-06135-A17).

\section{REFERENCES}

[1] Ciampitti, I. A., Vara, P. P. V. (2016): Historical synthesis-analysis of changes in grain nitrogen dynamics in sorghum. - Frontiers in Plant Science 7: 275.

[2] Ge, Z. Y., Ma, S. Y., Cheng, H. J., Yan, F. Z., Wang, L. X., Zhang, S., Sui, H. J., Pan, Y. $X$. (2016): Effects of different nitrogen on starch content in sorghum grains. - Journal of Northeast Agricultural Sciences 41(2): 25-29.

[3] He, P., Jin, J. Y., Li, W. J. (2005): Effect of potassium application on potassium absorption characteristics and grain yield of high oil corn and common corn. - Journal of Plant Nutrition and Fertilizer 11(5): 620-626.

[4] Jin, L., Cui, H., Li, B., Zhang, J. W., Dong, S. T., Liu, P. (2012): Effects of integrated agronomic management practices on yield and nitrogen efficiency of summer maize in North China. - Field Crop. Res 134: 30-35.

[5] Komla, K. G., Bertrand, M., Malick, N., Espoir, K. G., Aliou, G., Adam, M. (2019): Defining fertilization strategies for sorghum (Sorghum bicolor (L.) Moench) production under Sudano-Sahelian conditions. - Options for Late Basal Fertilizer Application Agronomy 9: 697.

[6] Kouich, M., Koji, K., Yuji, A., Kawasaki, T., Shimada, H., Baba, T. (1992): Starch branching enzymes from immature rice seeds. - Journal of Biochemistry 112: 643-651.

[7] Li, C. Y., Feng, C. N., Zhang, Y., Guo, W. S., Zhu, X. K., Peng, Y. X. (2005): The effect of nitrogen ratio on starch synthesis and related enzyme activity of weak gluten wheat Ningmai9. - Scientia Agricultura Sinica 38(6): 1120-1125.

[8] Li, S. B., Tang, C. C., Chen, F., Xie, G. H. (2018): Temporal and spatial changes in yield and quality with grain sorghum variety improvement in China. - Scientia Agricultura Sinica 51(2): 246-256.

[9] Liang, X. H., Liu, J., Cao, X. (2017): Effects of nitrogen application rate on yield of brewing sorghum and nitrogen use efficiency. - Acta Agriculturae Boreali-Sinica 32(2): 179-184.

[10] Mahama, G. Y., Prasad, P. V. V., Mengel, D. B., Tesso, T. T. (2014): Influence of nitrogen fertilizer on growth and yield of grain sorghum hybrids and inbred lines. Agronomy Journal 106(5): 1623-1630.

[11] Ni, Y. Q., Zhang, Q., Cao, F. Q., Yang, L. (2016): Effect of different nitrogen application on sorghum yield and plant nutrient accumulation. - Soil and Water Conservation Research 23(5): 95-99.

[12] Ronga, D., Caradonia, F., Setti, L., Hagassou, D., Giaretta, C. V., Milc, J., Pedrazzi, S., Allesina, G., Arru, L., Francia, E. (2019): Effects of innovative biofertilizers on yield of processing tomato cultivated in organic cropping systems in northern Italy. - Acta Hortic 1233: 129-136.

[13] Shen, H. J., Yang, S. R., Yang, G. Y., Shan, D. P., Tang, M., Sun, Z. H., Chen, L., Wang, F. M. (2013): Standardized cultivation techniques of dwarf sorghum Suiza7. - China Seed Industry 10: 57-58.

[14] Sun, X. S., Lin, Q., Liu, Y. G. (2008): The effect of the same amount of nitrogen application on the diurnal variation of photosynthesis in the filling stage of super high yield wheat. - Journal of Beinong 23(1): 58-162.

[15] Tan, C. X., Feng, C. N., Guo, W. S., Zhu, X. K., Li, C. Y., Peng, Y. X. (2016): Effects of gene expression of starch synthetase and starch synthesis in wheat grains. - Journal of Yangzhou University 37(2): 63-69.

[16] Tilman, D., Balzer, C., Hill, J., Befort, B. L. (2011): Global food demand and the sustainable intensification of agriculture. - Proc. Natl. Acad. Sci 108: 20260-20264. 
[17] Van weelden, M. T., Wilson, B. E., Beuzelin, J. M., Reagan, T. E., Way, M. O. (2016): Impact of nitrogen fertilization on Mexican rice borer (Lepidoptera: Crambidae) injury and yield in bioenergy sorghum. - Crop Protection 84: 37-43.

[18] Wang, J. S., Jiao, X. Y., Ding, Y. C., Dong, E. W., Bai, W. B., Wang, L. G., Wu, A. L. (2015): Response of grain sorghum nutrient absorption, yield and quality to nitrogen, phosphorus and potassium nutrition. - Acta Agronomica Sinica 41(8): 1269-1278.

[19] Wang, Q. (2006): Effect of Nitrogen Application on starch formation and accumulation in spring maize. Harbin, Heilongjiang. - Master Dissertation, Northeast Agricultural University, Harbin.

[20] Yan, H., Pan, X. X., Jiang, H., Wu, G. (2009): Comparison of the starch synthesis genes between maize and rice: copies, chromosome location and expression divergence. Theoretical and Applied Genetics 119(5): 815-825.

[21] Yang, D. G., Jin, J. Y., Li, W. J. (2005): Effect of potassium application on potassium absorption characteristics and grain yield of high oil corn and common corn. - Journal of Plant Nutrition and Fertilizer 11(5): 620-626.

[22] Yang, D. G., Niu, H. Y., Zhang, H. X. (2008): Effects of nitrogen stress and non stress on yield and quality of spring maize. - Maize Science 16(4): 55-57.

[23] Yang, G. D., Hu, Z. Y., Liu, L. L., Chen, L. Q. (2015): Cultivation techniques of sorghum in the north of Heilongjiang Province. - Heilongjiang Agricultural Sciences 5: 165-166.

[24] Yang, G. D., Zhou, Y. F., Huang, R. D., Lin, F., Hu, Z. Y., Hao, Z. Y., Liang, C. B., Wang, Q., Meng, X. X., Dong, L. D. (2019): Identification of differentially expressed genes of sorghum [Sorghum bicolor (L.) Moench] seedlings under nitrogen stress by RNA-seq. - Applied Ecology and Environmental Research 17(5): 11525-11536.

[25] Yi, B., Zhou, Y. F., Gao, M. Y., Zhang, Z., Han, Y., Yang, G. D., Xu, W. J., Huang, R. D. (2014): Effect of drought stress during flowering stage on starch accumulation and starch synthesis enzymes in sorghum grains. - Journal of Integrative Agriculture 13(11): 2399-2406.

[26] Yu, Y., Huang, R. D., Zhao, S. W., Jiang, W. C. (2008): Effect of nitrogen application on starch accumulation in sorghum grains. - Crops 15: 20-24.

[27] Zhao, H. W. (2003): Study on the mechanism of carbon and nitrogen metabolism under different nitrogen nutrition levels. Harbin, Heilongjiang. - Doctoral Dissertation, Northeast Agricultural University, Harbin.

[28] Zhou, L. B., Wang, C., Lu, X. J., Zhang, G. B., Xu, Y., Wu, L. Y., Shao, M. B. (2016): Effects of fertilization amount and planting density on photosynthetic characteristics, agronomic characteristics and yield of glutinous sorghum Qiangao7. - Journal of Southern Agriculture 47(5): 644-648. 